\title{
Nationalities Policy of the First Year of the Soviet Regime
}

\author{
Sergey A. Podyapolskiy* \\ Law firm "Crisis Management Group" \\ 8/9 Maerchak Str., Krasnoyarsk, 660075, Russia
}

Received 12.01.2018, received in revised form 26.04.2018, accepted 04.05.2018

On the basis of the primary sources of references, the author presents Lenin's nationalities policy not as a dogmatic implementation of a theoretically constructed doctrine, but as a flexible set of political tactics adequate to the current social and political situation, the task of retaining power, and other general political and economic tasks of the Soviet government. Among the tactical techniques used by the Bolsheviks at that time, the author studies declarations, promises, presents, tactical compromise, tolerance in exchange for political loyalty, using allies of the moment, forming ethnic military subdivisions, establishing central and local bodies of ethnosocial management, propaganda and campaigning, creating national and territorial autonomies and control over education institutions.

Keywords: Bolsheviks, Narkomnats, nation building, propaganda, soviet nationalities policy.

DOI: 10.17516/1997-1370-0271.

Research area: culturology.

The question of returning to Lenin's principals of nationalities policy was raised both in the years of the "thaw" and in the early "perestroika". That was the "violent abuse of the main Lenin's principles of the Soviet nationalities policy" N.S. Khrushchev accused J.V. Stalin of in his speech at the $20^{\text {th }}$ Congress of the Communist Party of the Soviet Union $^{2}$. In September 1989, at the Plenum of the Central Committee of the Communist Party M.S. Gorbachev announced, that "the Party would consistently employ Lenin's nationalities policy including its underlying principle, which is the nationalities' right to self-determination". At that, he suggested "to regard self-determination not as a single act of exercising right to secession. It is a comprehensive, sophisticated process of the establishment of national dignity, development of language and culture, strengthening political independence, economic and social progress" ${ }^{3}$.

"For the development of culture of international communication, it is required, inter alia, to do the outright important thing, which is to return the principle of free self-determination into the Constitution of the USSR and keep it inviolable... At that, the right to free secession itself shall be legalized and guaranteed. The USSR breakup fears are obviously exaggerated", wrote I.G. Kunitsyn in the year $1989^{4}$.

(C) Siberian Federal University. All rights reserved

* Corresponding author E-mail address: spodyapolsky@yandex.ru 
Meanwhile, such forms of searching for deep meaning are most natural for a tradition of interpetation of religious texts interpretation tradition. Similarly, the Cabbalists, interpreting the text of Torah in a special way, found a great deal of hidden knowledge, names of angels and other secret data.

The attempt to approach the works of V.I. Lenin, the famous atheist and materialist, who wrote his texts in the heat of political action, may be interpreted in two possible ways. Firstly, as claimed by E. Berne, "Every group has a hunger for heroes and tends to glorify primal leaders after their deaths by a process of euhemerization. These euhemeri are strong influences in making the group meaningful" 5 . Secondly, manipulation component should not be ignored.

In regard to theory, the Bolsheviks believed the nationalities question to be secondary and considered it as a part of wider problems, such as agriculture $^{6}$. However, just like the democrats in the $1980-\mathrm{s}$, in the race for power, they turned to the ethnical periphery for support ${ }^{7}$. As J.V. Stalin said, "had there not been previously oppressed peoples, who had been undermining the rears with their silent sympathy for Russian proletariat, in the rear of Kolchak, Denikin, Wrangel, or Yudenich... we would have never knocked any of those generals down. As we were attacking them, their rears started to fall apart"

It should be also noted, that many opponents of the Bolsheviks also attempted to bring the ethnic minorities into the fold. In particular, the Caucasian indigenous division was incorporated into the forces led by General L.G. Kornilov' ${ }^{9}$ On June 28, 1918, in his letter to German Emperor, P.N. Krasnov set his plans for creating a federative state, the Don-Caucasian Union incorporating the Don and Astrakhan forces, the Kalmyks of Stavropol Province, and, subsequently, the
Terrek Cossack Host and the peoples of the Northern Caucasus ${ }^{10}$. In September 1918, in the process of Ufa meeting, the "ethnic" Kazakh, Turk-Tartar and Bashkir governments signed the act for concentration of power over Russia in the hands of the Directory ${ }^{11}$. However, in this area the Bolsheviks were much more successful than their opponents.

*

Securing self-determination of nations was included into the Programme of the Russian Social Democratic Labour Party approved at the Congress in 1903 (paragraph 9). However, back in that period, in his article "The National Question in Our Programme", V.I.Lenin wrote: "our unreserved recognition of the struggle for freedom of self-determination does not in any way commit us to supporting every demand for national self-determination"12.

In the year 1916, in the theses titled "The Socialist Revolution and the Right of Nations to Self-Determination" V.I.Lenin expressed a different point of view: "The socialist revolution may break out ... in consequence of any political crisis", and any conflicts should be taken advantage for the purpose of "rousing revolutionary attacks upon the bourgeoisie"13. At that, Lenin understood the right of nations to selfdetermination only as "the right to independence in a political sense, the right to free, political secession from the oppressing nation" ${ }^{\text {"14. }}$

In March 1917, in his article "Against Federalism" J.V. Stalin wrote: "The solution of the national problem must be as practicable as it is radical and final, viz.:

1) The right of secession for the nations inhabiting certain regions of Russia who cannot remain, or who do not desire to remain, within the integral framework;

2) Political autonomy within the framework of the single (integral) state, with uniform 
constitutional provisions, for the regions which have a specific national composition and which remain within the integral framework"15.

At the $4^{\text {th }}$ (April) Conference of RSDLP (b) J.V. Stalin added two more provisions to the aforesaid: the laws guaranteeing free movement of all national minorities, and "integrated inseparable proletariat collective, the single party" for the proletaries of all nationalities ${ }^{16}$ ". According to the idea of J.V. Stalin, the peoples of Russia had to arrive at "the new voluntary brotherhood ${ }^{17}$.

The Bolsheviks were very critical of the attempt to divide Russian social democracy by nationalities. In 1912, V.I.Lenin decisively claimed that all social democrats, despite of their nationality, had to work at their local territorial party organizations. As a positive example, Vladimir Ilyich referred to the work of TransCaucasian party members, including Georgians, Armenians, Russians etc. ${ }^{18}$ Besides, V.I.Lenin criticized Polish socialists, who wished to separate from Russia, letting Russian proletariat deal with the overthrow of monarchy on their own. He insisted on absolute union of all social democrats ${ }^{19}$.

This way, the Bolsheviks were ready to sacrifice the integrity of the state for tactical purposes, but not the integrity of the Party. It was supposed that the framework for the new political structure would be the vertical of the Party.

That was the line the Bolsheviks had been working to arrange since the first months of the Soviet power. Along with that, as we will prove later, this approach was combined with admirable political pragmaticism. Assessing the reality in the most rational way, they could sometimes accept significant concessions. However, those were merely a tactical issue. As soon as their positions were solidified, the Bolsheviks did not hesitate to get rid of their hapless partners.
The Soviet nationalities' policy of the first years of the Soviet power was not a dogmatic implementation of a theoretically constructed doctrine. Lots of steps were improvised. Some of them turned out to be efficient, others never paid off, and the third required serious correction.

The expression "the Bolsheviks revived the Empire" may be only used as a metaphor. "Constantinople has to remain in the hands of the Muslims": it was explicitly conveyed to all the toiling Muslims of Russia and the East in the Appeal of the Council of the People's Commissars on November 20 (December 3) 191720. A greater gap from the Russian Empire ideology is hard to imagine. However, in their political practice, the Bolsheviks were struggling not only with the heritage of the Tsar's regime, but also against that of the Provisional Government. Having destroyed the previous system, the new government failed to create a new one. As a result, the country became simply unmanageable ${ }^{21}$.

Our hypothesis is that "Lenin's nationalities' policy" was a flexible range of tactical techniques aligned with the current social and political situation, the task of maintaining the authority and the general political and economic objectives of the Soviet government.

The first of such tactical techniques were declarations and promises. In this regard, the Bolsheviks were much more successful than their opponents. Even N. Machiavelli advised the Tsar to make more promises. However, the thinker specified, that "a wise lord cannot, nor ought he, keep faith when such promises may be turned against him, and when the reasons that caused him to promise no longer exist ${ }^{22}$ ".

The Decree of Peace, enacted by the $2^{\text {nd }}$ AllRussian Congress, called for immediate peace "without annexations". Those were defined as 
"every incorporation of a small or weak nation into large or powerful state without the precisely, clearly, and voluntarily expressed consent and wish of that nation ${ }^{23}$ ".

On November 3, 1917, the Decree of the Council of the People's Commissars approved the Declaration of Rights of the Peoples of Russia. This document established the principles determining the nationalities' policy of the Soviet authorities: "the equality and sovereignty (italics by the author) of the peoples of Russia", their right to secession and to form an independent state, cancellation of all national limitations and free development of national minorities within each of the peoples ${ }^{24}$.

On December 7 (November 24) 1917, the Appeal of the Council of People's Commissars "To the Muslims of Russia and the East" was published. Particularly, it said: "Muslims of Russia, Tatars of the Volga and the Crimea, Kirghiz and Sarts of Siberia and Turkestan, Turks and Tatars of Trans-Caucasia, Chechens and mountain Cossacks! All of you, whose mosques and shrines have been destroyed, whose faith and customs have been violated by the Tsars and oppressors of Russia! Henceforward your beliefs and customs, your national and cultural institutions, are declared free and inviolable! Build your national life freely and without hindrance. It is your right. Know that your rights, like those of all the peoples of Russia, will be protected by the might of the revolution, by the Councils of Workers', Soldiers', and Peasants' Deputies! $!^{25}$

On December 29, 1917 (January 11, 1918) the Decree on Turkish Armenia was enacted. It declared withdrawal of Russian troops, immediate creation of Armenian national police (militsia), unimpeded return of Armenian refugees and emigrants. It also specified, that the Council of People's Commissars will insist on unimpeded return of the Armenians who during the war were forcibly exiled inside Turkey by the Turkish authorities, to "Turkish Armenia". It was also suggested to establish an Interim Government in Turkish Armenia as a Council of Deputies of the Armenian people elected on the principle of democracy ${ }^{26}$. As Makarova delicately commented, the "Trans-Caucasian circumstances" obstructed the implementation of the decree ${ }^{27}$.

One of the most significant acts was the Declaration of Rights of the Working and Exploited People. The draft of the document was initially prepared for the Constituent Assembly. The document was approved three times: first, by All-Russian Central Executive Committee, and then twice (for the new edition) by the $3^{\text {rd }}$ Russian Congress - on January 12 (25) and 18 (31) $)^{28}$. The new edition of the text was also incorporated into the RSFSR Constitution 1918.

According to the Declaration, the new state was established "on the principle of a free union of free nations, as a federation of Soviet national republics"29. The resolution of the $3^{\text {rd }}$ All-Russian Congress of Soviets, enacted as a result of the Declaration discussion, stated that "The All-Russian Congress of Soviets of Workers' and Soldiers' Deputies welcomes and entirely approves of the nationalities policy of the Government of the People's Commissars, targeted at the implementation of the principle of selfdetermination, understood as self-determination of the labour masses of all nations of Russia ${ }^{30}$ ".

On June 10, 1918, the Fundamental Law was approved by the $5^{\text {th }}$ All-Russian Congress of Soviets, and nine days later it was published in "Izvestia USSR Central Executive Committee" newspaper, and since that moment it was deemed enacted. According to the document, the RSFSR was a federation constituted by both administrative and territorial entities as well as autonomies, established on the ground of their ethnic composition. Article 22 of the 
Constitution recognized "the equal rights of all citizens, irrespective of their racial or national connections", and forbade "all privileges on this ground, as well as oppression of national minorities ${ }^{31}$ ".

On August 29, 1918, the treaties on the division of Poland were declared cancelled ${ }^{32}$.

The Bolsheviks were much more successful in bringing ethnic minorities to the fold than their opponents. They were also committed to take it further. In August 1918, G.K. Ordzhonikidze called the Chechens and Ingushes to give support to the defenders of Vladikavkaz, promising them the Cossack lands for that ${ }^{33}$. Alone with that, on November 25 (December 8), the inefficient appeal to the working Cossacks on the conquests of the October Revolution and struggle against counterrevolution was enacted.

In autumn 1918, in Moscow, the headquarters for establishing Chinese detachments in the territory of the RSFSR were opened ${ }^{34}$. The Bolsheviks succeeded to recruit hundreds of thousands of labour migrants brought to Russia during the World War I.

Besides promises, the Bolsheviks were good at gift giving. In November 1917, the Ukrainian fraction of the Central Executive Committee received the banners, bunchuks and charters seized during the reign of Catherine the Great ${ }^{35}$. In December 1917, the Council of People's Commissars resolved to give the Samarkand Kufic Quran, stored at the State Public Library, to the Congress of Muslims ${ }^{36}$. In January 1918, V.I.Lenin approved the delivery of Söyembikä Tower in Kazan and Caravanserai in Orenburg to the Tatars and Bashkirs, correspondingly. Together with that, the cross on top of Söyembikä was replaced with a crescent ${ }^{37}$. The same month, the Decree on Protection of the pieces of history and art belonging to the Polish nation was enacted ${ }^{38}$.
As it has been said above, the Bolsheviks expressed a certain kind of "revolutionary pragmaticism".

First of all, the pragmaticism manifested itself in recognition of the actual facts. Thus, the Declaration of Rights of the Working and Exploited People "welcomes the policy of the Council of People's Commissars in proclaiming the complete independence of Finland, commencing the evacuation of troops from Persia, and proclaiming freedom of selfdetermination for Armenia".

Secondly, the pragmaticism was expressed as a readiness to compromise when necessary and not to force events in the lack of resources.

On April 3, 1918, the Council of the People's Commissars of the Turkestan Autonomous Soviet Socialist Republic rejected the premature plan of implementing the Soviet judicial system: “... The previous judicial system remains acting in the land of Turkestan, but the personnel composition of the court ... is supplemented with the democratic representatives of the Soviets ${ }^{39}$ ".

In the Northern Caucasus, in the 1917-1918 a system of Sharia courts (sharsud) was created; the sharsuds were the successors of the formally abolished municipal and public courts. In Dagestan, the sharsuds remained acting until the year 1927. The basic structure of the executive authorities was still the local community, which gained more power after the revolution. They served as a foundation for the administrations of rural councils (selsovet) and collective farms $(\text { kolkhoz })^{40}$.

"In the years 1920-22 we could not influence the results of the elections in the Circassian auls, and relied only on mullahs, seniors, and with their help established the Soviet authority in Adygea", remarks the chairman of the Oblast Executive Committee Sh.U.Khakurate. "There were hardly any poor or middle-class peasants in 
the Soviets" ${ }^{\text {"41 }}$. Historian S. Konstantinov stated, that in 1923 the 50 percent of the Party structure of Khwarezm town consisted of merchants and only 10 percent - of the clergy ${ }^{42}$.

\section{$*$}

The tolerance for self-determination and originality was based on political loyalty. In this regard, let us turn to the Manifesto to the Ukrainian People with an Ultimatum to the Ukrainian Rada of December 4 (17), 1917. The Council of People's Commissars declared recognition of both the People's Republic of Ukraine and its right to independent foreign policy, and the "national rights and national independence". Alone with that, the CPC accused the Rada of "conducting a doubledealing bourgeois policy", which "has long been expressed in the Rada's non-recognition of the Soviets and of Soviet power in the Ukraine". In particular, "Rada has started to disarm the Soviet troops stationed in the Ukraine" and "Rada has been extending support to the Cadet-Kaledin plot and revolt against Soviet Power... Rada has allowed its territory to be crossed by troops on their way to Kaledin" ${ }^{43}$ ".

Due to the failure in negotiations with the Rada, the Council had to appeal directly to the proletariat and peasants. In the Appeal to the Ukrainian Workers, Soldiers, Peasants, all Ukrainian Peoples of December 8 (21) 1917, it was proclaimed: "Demand immediate re-election of the Rada. Demand all Ukrainian power to be assigned to the councils of workers, soldiers and peasants' deputies. Let the Ukrainians prevail in the Councils". Let the Soviet power be established" ${ }^{\prime 4}$.

$*$

As it has been said above, in the beginning, the Bolsheviks were ready for a dialogue with other political forces. For instance, in Ukraine one of the allies of the Bolsheviks was the
Party of Poale Zion, a radical left Jewish social democratic party. Later, its left wing formed the Jewish Communist Party (JCP), which was incorporated into the Russian Communist Party of the Bolsheviks ${ }^{45}$.

According to G.P. Makarova, on a local scale a "certain specificity in the manner of work" was allowed $^{46}$. If the power of the Bolsheviks was insufficient, they recruited people who shared their ideas at least partially, or had any interest in cooperation with the new authorities ${ }^{47}$.

Thus, on June 17, 1918, the Council of People's Commissars instructed all parish and provincial councils "in the places of Muslim presence" to organize local Muslim commissariats. The task was assigned to the "left revolutionary organizations of the Muslims, standing on the platform of the Communists or left revolutionary socialists ${ }^{48}$ ".

Similarly, in June 1918, all parish and provincial councils of the workers and peasant deputies of the Northern Caucasus, Dagestan, Black Sea and Stavropol provinces were instructed "in the places of montane population residence" immediately to organize departments of montane population affairs. The task was assigned to the "left revolutionary organizations of the montane population, standing on the Soviet platform"49.

Narkomnats also communicated with the Communist organizations of internationalists, the captured soldiers of the German and AustroHungarian armies ${ }^{50}$.

In June 1918, in Kazan, the All-Russian Congress of Communist Muslim Organizations was held. As a result, an independent Russian Muslim Communist Party with its own Central Committee was created. In autumn of the same year, the independent Chuvash Communist Committee, not incorporated into Russian Communist Party of the Bolsheviks, was established $^{51}$. 
Baku played a special role both for TransCaucasian Region and in a wider context, since before the war it concentrated around $80 \%$ of Russian and $15 \%$ of the total world volume of oil extraction ${ }^{52}$. In October 1917, the local Bolsheviks, who in spring of the same year had constituted only one sixth part of the local Council of Workers' Deputies, began their open struggle for power. By the end of the year they had established their control over the whole industrial district of $\mathrm{Baku}^{53}$. Many of Baku Commissars were Armenian or Russian. Perhaps, this was the reason why, starting from the 1990-s, many researchers and opinion journalists regarded their activity as a plot of Armenian nationalists and their allies against the Democratic Republic of Azerbaijan ${ }^{54}$. The Soviet power ruled Baku until September 15, 1918. After the city got captured by Turkish and Azerbaijani troops, from 30 to 35 thousand local residents, predominantly, Armenians, were slaughtered ${ }^{55}$.

The situation in Turkestan was a paradox. Initially, the Soviet power relied on Russian immigrants (including railway workers) and was purely ethnical. For instance, the Council of Tashkent, representing workers and soldiers, announced: "Currently, involving Muslims into the bodies of the regional top revolutionary authority is unacceptable, since due to absolute uncertainty about the attitude of the indigenous population to the authority of the soldiers, workers and peasants' deputies, as well as due to the fact that among the locals there are no proletary class organizations, whose representatives would be welcome in the top governmental bodies ${ }^{56}$ ".

At the $6^{\text {th }}$ Extraordinary Congress of Soviets of the Turkestan Republic in 1918, the activity of Turkestan Committee for Nationalities Policy was harshly criticized. Particularly, it was pointed out that very few representatives of local workers got elected into the governmental bodies ${ }^{57}$.
Later, the policy of the Soviets in the region adopted another extreme solution. As I.Iu. Morozova claims, many Russian peasants were declared to be "kulaks", and the Semirechensk Cossack community was massively repressed as a reactionary class ${ }^{58}$.

In the situation of the Civil War, it became vital to take account of the ethnical factor in military arrangements. The Soviet authorities had to neutralize the hostile ethnical subdivisions, some of which had been created before the Revolution. However, not long after that, they gained their own experience.

The Order on the establishment of the first Tatar-Bashkir infantry battalion of the Red Army was signed by the Chairman of the Muslim Commissariat M. Vakhitov on April 1, 1918. It was formed of working Muslims from Moscow, as well as workers from Turkestan, mobilized for rear works in 1916. The subdivision was created for the struggle against the Trans-Bulak Republic created by Tatar nationalists.

On May 7, 1918, the establishment of ethnic subdivision was also approved by the Narkomnats collegiate. On 24 May, the People's Commissariat for Military Affairs agreed. Initially, it was suggested to create ethnic military units of a level not higher than a troop, squadron or battery. The first Tatar-Bashkir battalion was successfully established, and the second one followed soon. Estonian division of Narkomnats established the first Estonian regiment ${ }^{59}$. Soon, some divisions were created (Belebey Bashkir division) ${ }^{60}$.

On June 14, 1918, the Appeal to All the Toiling Muslims to enter the Muslim Socialistic Army was published ${ }^{61}$. It was signed by V.I. Lenin and M. Vakhitov. "If you want to be free citizens in the tortures of the arising Tatar-Bashkir Soviet Republics, hurry under the red banners of the Muslim Socialist Army" ${ }^{\prime \prime}$. 
The ethnic military units were also established in the Northern Caucasus. The same year, the Dagestani Horse Regiment was formed $^{63}$.

In October, 1918, the First Exemplary Soviet Kazakh Regiment was created ${ }^{64}$. It was not an easy task, since before the Revolution the Kazakhs had not had compulsory military service. However, the experiment was a success. Soon, other Kazakh units were established. Remarkably, in the Soviet Kazakh press they were positioned as a regular army of the Kazakh people, which in fact they had not had for centuries ${ }^{65}$.

Active spoken and printed propaganda, including that in ethnic languages, was carried out among the Red Army soldiers. The political department of the $2^{\text {nd }}$ army published its Krasnyy Voin (The Red Warrior) newspaper in Mari, Udmurt, Chuvash, and Tatar languages. The Central Muslim Military Collegiate published Krasnaia Armiia (The Red Army) newspaper ${ }^{66}$.

One of the first authority bodies of the USSR established under the Decree of October 26 (November 8) 1917, was the People's Commissariat of Nationalities, which had been functioning until 1923 under permanent command of J.V. Stalin. Among the objectives of this body, there were, security of peaceful co-living and brotherly cooperation of all nationalities and tribes of the RSFSR, as well as contractual friendly Soviet republics, assistance their material and spiritual development as applicable to their lifestyle, culture and economy, supervision over the implementation of nationalities policy of the Soviet authorities ${ }^{67}$. Narkomnats included Polish, Belorussian, Latvian, Jewish, Armenian and Muslim (since 1918: Tatar-Bashkir) commissariats (since 1920: departments), as well as departments for the affairs of Estonians, Volga Germans, Kyrgyz, Kalmyks and the Caucasus peoples. J.V.Stalin, as recalled by his deputy S.S. Pestkowski, personally supervised the policy in respect of the Eastern peoples, entrusting him with the work among the Western ethnicities, such as the Polish, Latvians etc. ${ }^{68}$.

E.K.Mineeva notices, that "the People's Commissariat of Nationalities of the Soviet Republic was the first Russian body consisting exclusively of non-Russians. The People's Commissar and the most well-known officers, such as S.M.Dimanstein, S.S.Pestkowski, V.S.Mickevičius-Kapsukas and many others were authorized not only as public officials, but also as representatives of the national culture of their Georgian, Jewish, Polish, Lithuanian and other ethnicities correspondingly ${ }^{69}$ ".

V.G. Chebotareva points out at the opposition of two inclinations in the Narkomnats activities, the great-power chauvinism and bourgeois nationalism ${ }^{70}$. There were lots of disputable issues. For instance, at the meeting of July 27, 1918, Narkomnats raised the question, whether the collegiate should be based upon the national or political principle. It was resolved to form it of nine people selected with the political principle. However, during the personal selection the nationalities question was raised again ${ }^{71}$.

One of the main activities of Narkomnats was publishing. Even in the first year of its work, the body issued newspapers in over twenty languages, though before the Revolution the nonRussian peoples had hardly had any periodicals in their mother tongues ${ }^{72}$. By the end of 1920, Narkomnats had been issuing sixty newspapers (with the third of them being Muslim). Over seven hundred books and brochures were published in the number exceeding twelve million copies $^{73}$. Besides newspapers, the formats of fliers and posters were also widely used. Thus, Chuvash department printed 100000 copies of "The Tsar, Pope and Kulak" poster ${ }^{74}$. In the Middle Asia with the great illiteracy rate, public readings were 
of great popularity. For this purpose, the "red wagons" and "red arabas" were made ${ }^{75}$.

$*$

The Bolsheviks were extremely active in establishing local units. There was a far-reaching network of National Commissariat Departments. Thus, by the middle of the year 1918, the departments of Lithuanian Commissariat had been created in forty-four cities. From Siberia and Middle Asia to Baku and Belorussia, there were Commissariat Departments for Armenian Affairs ${ }^{76}$.

The departments were assigned, particularly, with "implementation of the Soviet policy in the environment of the corresponding nationalities" and "fight against counter-revolution in the ethnic environments"

The Muslim Bolsheviks of Kazan established Kazan Muslim Committee as an opposition to the All-Russian Muslim Military Congress ${ }^{78}$. They claimed that their opponents, "the Tatar bays go side by side with the Russian clergy and Russian moneybags"79. Orenburg Commissariat was opposed to Bashkir kutultay and Bashkir Interim Government, acting in contact with the Ataman A.I. Dutov. Ufa Commissariat was created as an alternative to Millet Meclese and the National Administration of Muslims of the Inner Russia and Siberia. These structures were financed through Narkomnats ${ }^{80}$.

On July 26, 1918, the Council of People's Commissars declared: "From the point of view of the public interests, any unauthorized actions of the local Councils in relation to the colonist Germans may cause quite sad consequences... For this reason, it is suggested... to act in a tight cooperation with the German Commissariat, and in case of discrepancies, consult the Council of the People's Commissars ${ }^{81}$ ".

In March 1918, the Decree of the CPC on the liquidation of the disobeying Armenian Military Commissariat, having its local branches in various cities of the RSFSR, was issued ${ }^{82}$. Soon, the same fate was shared by the National Administration of Muslims (Milli Idare) and AllRussian Muslim Council (Milli Shuro), as well as the Supreme Lithuanian Council ${ }^{83}$.

The national and territorial autonomies were positioned as the main Soviet way of resolving the "national question". Thus, in his work "Marxism and the National Question", J.V.Stalin claimed: "The only correct solution is regional autonomy, autonomy for such crystallized units as Poland, Lithuania, the Ukraine, the Caucasus, etc. ${ }^{84}$ ".

In spring 1918, in the process of development of the first RSFSR Constitution, there rose a conflict between the responsible officer of the People's Commissariat of Justice, the political scientist M.A. Reisner and the People's Commissar for Nationalities J.V.Stalin. The first one, believing the national question to be a relic of feudalism, considered the RSFSR to be a federation of "toiling communes". In the opinion of O.I. Chistiakov, the idea was not bad, but in 1918, when the national movements were stronger, it was "impracticable and dangerous". The second suggested building the federation on the national-territorial principle. The Constitution draft development Commission approved the suggestion of J.V. Stalin with the majority of five votes against three ${ }^{85}$.

Together with that, for Stalin, the federation was a tool, not a purpose. In May 1918, he claimed that in the current historical situation the country needed "strong All-Russian authority that would finally oppress the enemies of socialism and organize a new, communist economy" ${ }^{\prime \prime 6}$. One month before that, in an interview to Pravda newspaper, Stalin expressed an opinion that federalism in Russia was doomed to be a transit point on the way to the future socialist unitarianism $^{87}$. 
In practice, the Soviet autonomy system was developed with the method of trial-and-error. In this regard, the attempt of creating the TatarBashir Republic is especially remarkable. Many national Communist leaders spoke against the idea $^{88}$. On April 13, 1918, the General Meeting of the Chuvash, Cheremiss, and Kryashen-Tatr Socialist Committees, standing on the platform of the Soviet power, and the Commissariats for National Affairs, also disapproved the "tendency for establishing the Muslim hegemony... to the prejudice of small-numbered peoples ${ }^{89}$ ". The All-Chuvash Congress proclaimed that it did not "recognize the need of creating the Tatar-Bashkir Republic and incorporating Chuvash population into it ${ }^{90}$ ".

Various options were considered. In May 1918, J.V.Stalin offered "dividing the residents of the area... not by nationality, but by the class the belong to" ${ }^{\prime 1}$. On May 16, 1918, the majority of the Narkomnats meeting members approved the Provision on the Tatar-Bashkir Republic, though some provincial representatives were against. Five Communists left the meeting ${ }^{92}$.

On June 13, 1918, the meeting of delegates of the Chuvash, Mari, Kryashen and Votyak Congresses of workers and peasants voted against joining the planned republic ${ }^{93}$. In June 1918 in Ufa, the Ural Oblast Council Newsletter (Izvestiia of the Urals Oblast Council) published an open letter of G.-A. Aitbaev to J.V. Stalin: "The Ufa Tatars call to kill every person who opposes the Tatar-Bashkir Republic... The Bashkir people is economically bound to Russians; the Russian people is more likely to support us materially and spiritually than the Tatars who have long been striving to have the Bashkirs assimilated ${ }^{94 "}$.

In some cases, the Bolsheviks acted according to the situation. Thus, the preparation of the Kazakh autonomies, which began in April 1918, was, to a great extent, a reaction to the government of Alash-Orda, created by the
Kazakh nationalists in December 1917. Formally recognizing the Soviet authorities, the latter demanded recognition of its control over the Kazakh areas ${ }^{95}$.

In respect of the Belarusians, the Bolsheviks worked "proactively". Just like the local Soviet and Party bodies, the Belarus Commissariat initially suggested that creation of an autonomous republic within the RSFSR would be enough for self-determination of the Belarusians ${ }^{96}$.

From the memories of D. Buniatzade we conclude, that in November 1918, after the closure of the First Congress of Muslim Communists in Moscow, he spoke to V.I.Lenin and informed him of the two points of view existing in the environment of the Azerbaijani revolutionaries. The first one stated the need for creation of an independent Soviet Socialistic Republic, and the second called for the division of Azerbaijan into provinces and conjoining it to the RSFSR. V.I.Lenin inclined to the first option, referring to the second as to "colonizership and stupidity"97.

Putting the national-territorial principle of state structure into practice, the Bolsheviks faced the problem of extensive settlement of the major part of the ethnic groups. As remarked by V.I.Kozlov, historically, many large cities in the ethnic regions grew and developed, being populated predominantly by Russians. For example, it is true for Saransk in Mordovia, Ufa in Bashkiria etc. ${ }^{98}$

Moreover, this common start often contradicted the economic principle, which required accounting for the natural, geographic, industrial peculiarities of the country, the size of its territory, number and density of population, inclination for certain economic centres, direction and character of transportation lines and location of industrial capacities ${ }^{99}$. As a result, V.I.Lenin concluded: "To cut the towns off from the villages and areas that economically gravitate 
towards them, for the sake of the "national" factor, would be absurd and impossible" ${ }^{100}$. In December 1920, the $8^{\text {th }}$ All-Russian Congress of Soviets confirmed the rationality of division based on the economic factor ${ }^{101}$.

The Bolsheviks rejected the non-territorial, national-cultural autonomy ${ }^{102}$, suggested by Austrian Marxists O. Bauer and K. Renner, who worked to develop forms of representation of the numerous ethnical groups scattered around the Austro-Hungarian Empire. They spoke about creation of non-territorial institutions, for the ethnic groups to find representatives and institutional support ${ }^{103}$.

This concept was criticized, particularly, in the pre-revolutionary work by V.I.Lenin titled "Critical Remarks on the National Question". There he wrote: "securing the separation of all nations from one another by means of a special state institution-such is the ideological foundation and content of cultural-national autonomy ${ }^{104}$ ". V.I.Lenin strongly disagreed with the suggestion to give public education to the hands of the cultural-national autonomies: "To advocate this invention is to advocate the division of school education according to nationality, and that is a downright harmful idea ${ }^{105}$ ". At the same time, he saw nothing impossible in satisfying "all the reasonable and just wishes of the national minorities ${ }^{106}$ ", including using the languages of such minorities in education. However, it required an integrative policy in the sphere of public education.

In his work "Marxism and the National Question" (1913), J.V.Stalin announced that providing cultural-national autonomy to the numerous small peoples of the Caucasus (for example, the Ossetins and Mingrels) meant holding them back at the lowest stages of development and assisting the political reaction.
Joseph Vissarionovich considered the oblast autonomy, associated with providing the national minorities with the right to speak their mother tongue and have their own schools, to be a more acceptable way of regulating inter-ethnical relations, since it helped the backward peoples to get over their national isolation. Following V.I.Lenin, he harshly criticized the idea of creating labour parties on the ethnical basis ${ }^{107}$. In the year 1918, J.V. Stalin emphasized: "The obtuseness of the Austrian Social-Democrats of the type of Bauer und Renner consists in the fact that they have not understood the inseparable connexion between the national question and the question of power ${ }^{108}$ ".

It looks like one of the reasons for rejection of the national-cultural autonomies was the fear of the competition the autonomous would present to the party vertical of power, being organized in a hierarchy, with their own central bodies and provincial representatives. Similarly, according to the Law of the year 1867, the district councils were forbidden to enter into direct business contacts with each other ${ }^{109}$.

This point of view can be confirmed with the Thesis of Domestic Policy, enacted in August 1922 by the Far East Bureau of the Central Committee of Russian Communist Party of the Bolsheviks and the Government of the Far East Republic. Particularly, the document restricted national self-government "strictly to the residence area of the group, such as a town or a settlement, without centralized conjunctions (italics by the author)". It was suggested to follow this strategy at least as long as the cultural-national autonomy bodies can "provide the domination of Communists and sympathizing non-members ${ }^{110}$ ".

Just like any other power, the Bolsheviks had to solve one of the basic problems of any politically organized community: maintenance 
of civilian peace, and, particularly, termination of ethnic conflicts. The Soviet Government was extremely decisive about this issue. On July 25,1918 , in response to the Jew bashing in the frontline area it was prescribed to put any pogromschiki and those leading pogrom propaganda... "outside the law ${ }^{111}$ ".

However, the settlement of ethnic conflicts was combined with an intensive struggle against the political and class enemies On September 5, 1918, the Decree on Red Terror was enacted. It prescribed to "secure the Soviet Republic from the class enemies by isolating them in concentration camps". All persons participating in the White Guard organizations, conspiracies and rebellions had to be sentenced to shooting ${ }^{112}$.

\section{$*$}

An illiterate person stands outside politics, he must first learn his $A B C$. V.I. Lenin ${ }^{113}$

The enlightenment of the national minorities happened to be on the borderline between the competences of Narkomnats and Narkompros (Council of People's Commissariat for Education). The Narkomnats departments were doing a great job on establishment and development of national schools. However, this process was often accompanied with a comb-out. For instance, at Lithuanian schools, "reactionaries and clericalists" were dismissed from teaching. The fight against the "ideological influence of bourgeoisie" was carried out by the Armenian Commissariat of Narkomnats ${ }^{14}$.

Along with that, the Narkomnats officers often had to control the plans of their colleagues from Narkompros. For example, despite the Decree of Narkompros of December
11, 1917 on handing over the religious schools to the public education departments of the Executive Committees of the Soviets, the schools got under control of the local Muslim Commissariats. The finance was forced from Narkompros through the Central Muslim Committee and Narkomnats ${ }^{115}$.

As a result, in October 1918, on the basis of an agreement concluded between the two commissariats, the National Minorities Education Department of Narkompros was established. The same month, the State Committee for Public Education of Narkompros of the RSFSR enacted the Decree on National Minorities' Schools, where it determined teaching to be carried out in the ethnic language under the common syllabus. The same time, writing development programmes were made for the peoples who had no writing.

Back in the 1920-s, Turkestan Narkompros allowed teaching Muslim doctrine at Soviet schools. Narkomnats of the RSFSR, though formally criticized the approach, in practice agreed to compromise, allowing teaching the subject to outsourced teachers during time free of the main classes ${ }^{116}$.

The word "alien" was pushed out from use; to replace, the terms of "national minorities", or, shortly, "natsmen" were introduced. The teaching activists were referred to as "natsional" 17 . The struggle for the purity of mother tongues was combined with a great number of adoptions from the Soviet social-political terminology ${ }^{118}$.

This way, "Lenin's nationalities policy" was not a dogmatic implementation of a theoretically constructed doctrine, but as a flexible set of political tactics adequate to the current social and political situation, the task of retaining the power and general political and economic tasks of the Soviet government.

\footnotetext{
See, for example: Iakunin, V.I., Bagdasarian, V.E., Sulakshin, S.S. (2009). Novye tekhnologii bor'by s rossiyskoy gosudarstvennost'iu [New Technologies of Fight Against the Russian State]. Moscow: Nauchnyy Ekspert. P. 225.

2 Speech of Khrushchev at the 20th Congress of the Party. Available at: http://www.coldwar.ru/hrushev/cult_of_personality.php
} 
3 O natsional'noy politike partii v sovremennykh usloviiakh. Doklad General'nogo sekretaria TSK KPSS M.S. Gorbacheva. 19 Sentiabria 1989 g. Materialy Plenuma Tsentral'nogo Komiteta KPSS, 19-20 sentiabria 1989 g. [On the Nationalities' Policy of the Party in the Modern Conditions. The Speech of the General Secretary of the Central Committee of the Communist Party of the USSR Gorbachev, M.S. September 19, 1989. Proceedings of the Plenum of the Central Committee of the Communist Party of the Soviet Union, September 19-20, 1989]. Moscow: Politizdat, 1989. P. 25-26.

4 Kunitsyn, I.G. (1989). Samoopredelenie natsiy - istoriia voprosa i sovremennost' [Self-Determination of Nations: History and Contemporariness], In: Voprosy filosofii [Philosophy Questions]. No. 5. P. 85.

5 Berne, E. (2008). Lider i gruppa. O strukture i dinamike organizatsiy i grupp [Lider and Group. Structure and Dynamics of Organizations and Groups]; Eric Berne [translated from English by A. Gruzberg]. Moscow: Eksmo. P. 58.

6 See: Stalin, J.V. (1946). Marksizm i natsional'nyy vopros [Marxism and the National Question], In: Stalin, J.V. Sochineniia [Works]. Vol. 2. Moscow: OGIZ.P. 319.

Tishkov, V.A. (2005). Etnologiia i politika [Ethnology and Politics]. Moscow: Nauka. P. 34.

8 Stalin, J.V. (1947). XII s'ezd RKP (b). Doklad o natsional'nykh momentakh v partiynom i gosudarstvennom stroitel'stve [12 ${ }^{\text {th }}$ Congress of the RCP (b). Speech on the National Moments in the Party and State Building], In: Stalin, J.V. Sochineniia [Works]. Vol. 5. Moscow: OGIZ.P. 246.

9 See: Volkhonskiy, M., Mukhanov, V. (2007). Po sledam Azerbaydzhanskoy demokraticheskoy respubliki [Following Azerbaijan Democratic Republic], Moscow: Europe Publishing House. P. 43.

10 See: Krasnov, P.N. (2003). Na vnutrennem fronte; V donskoy stanitse pri bol'shevikakh; Vsevelikoe Voysko Donskoe [At the Domestic Frontline. In a Don Stanitsa in the Time of Bolsheviks; The All Great Don Host]. Moscow: Ayris Press. P. 263.

11 See: Carr, E. (1990). Istoriia Sovetskoy Rossii. Kn. 1: Tom 1 i 2. Bol'shevistskaia revoliutsiia. 1917-1923 [A History of Soviet Russia. Book 1: Volumes 1 and 2. Bolshevik Revolution. 1917-1923]. Translated from English/Introduction by Nenarokov A.P. Moscow: Progress. P. 279-280.

12 Lenin, V.I. (1967). Natsional'nyy vopros v nashey programme [The National Question in Our Programme], In: Lenin, V.I.PSS [Complete Works]. 5th edition. Vol. 7. Moscow: Publishing House of Political Literature. P. 233.

13 Lenin, V.I. (1969). Sotsialisticheskaia rezoliutsiia i parvo natsiy na samoopredelenie [Socialist Revolution and the Right of Nations to Self- Determination], In: Lenin, V.I. PSS [Complete Works]. 5th edition. Vol. 27. P. 255.

14 Ibid.

15 Stalin, J.V. (1946). Protiv federalizma [Against Federalism], In: Stalin, J.V. Sochineniia [Works]. Vol. 3. Moscow: OGIZ. P. 27-28.

16 Stalin, J.V. (1946). VII (aprel'skaia) konferentsiia RSDRP (b). Zakliuchitel'noe slovo po natsional'nomu voprosu. 29 aprelia [7th (April) Conference of Russian Socialist Democrat Labour Party of the Bolsheviks. Final Word on the National Question. April, 29], In: Stalin, J.V. Sochineniia [Works]. Vol. 3. Moscow: OGIZ. P. 55.

17 Stalin, J.V. (1947). Politika pravitel'stva po natsional'nomu voprosu [Policy of the Soviet Government on the National Question in Russia], In: Stalin, J.V. Sochineniia [Works]. Vol. 4. Moscow: OGIZ.P. 229.

18 See: Tucker, R. (1991). Stalin. Put' $k$ vlasti 1879-1929. Istoriia i lichnost' [Stalin as Revolutionary. 1879-1929. History and Personality]. Translated from English, edited and afterword by Lel'chuk, B.S. Moscow: Progress. P. 146-147.

19 Lenin, V.I. (1967). Proekt rezoliutsii o meste Bunda v RSDRP [Draft Resolution on the Place of the Bund in the Party], In: Lenin, V.I. PSS [Complete Works]. 5th edition. Vol. 7. Moscow: Publishing House of Political Literature. P. 245.

20 See: Ko vsem trudiaschhimsia musul'manam Rossii i Vostoka [Appeal to the Moslems of Russia and the East], In: To All the Toiling Muslims of Russia and the East, In: Dekrety Sovetskoy vlasti [Decrees of the Soviet Authorities]. Vol. I. P. 114.

${ }_{21}$ See, for example: Omel'chenko, N.A. (2008). Istoriia gosudarstvennogo upravleniia v Rossii [History of State Administration in Russia]. Moscow: Prospect. P. 307.

22 Machiavelli, N. (1990). Gosudar' [Prince]. Moscow: Planeta, P. 52.

23 Cit ex: Carr, E. Op. cit. P. 217.

24 See: Declaration of the Rights of the Peoples of Russia. Available at: http://ru.wikipedia.org

25 Ko vsem trudiashchimsia musul'manam Rossii i Vostoka [To All the Toiling Moslems of Russia and the East] (1917). In: Gazeta vremennogo Rabochego i Krest'ianskogo Pravitel'stva [Newspaper of the Interim Government of Workers and Peasants]. December, 7 (November, 24). Available at: http://constitution.garant.ru/history/act1600-1918/5310/

26 Dekrety Sovetskoy vlasti [Decrees of the Soviet Authorities]. Vol. I. October 25, 1917 - March 16, 1918. Moscow: State Publishing House of Political Literature, 1957. P. 298-299.

27 See: Makarova, G.P. (1987). Narodnyy komissariat po delam natsional'nostey RSFSR. 1917-1923 gg. Istoricheskiy ocherk [People's Commissariat for Nationalities in the RSFSR. Years 1917-1923. Historical Essay]. Moscow: Nauka. P. 36.

28 See: Dekrety Sovetskoy vlasti [Decrees of the Soviet Authorities]. Vol. I. P. 321, 342.

29 Ibid.

30 Dekrety Sovetskoy vlasti [Decrees of the Soviet Authorities]. Vol. I.P. 351.

31 Konstitutsiia (Osnovnoy zakon) Rossiyskoy Sotsialisticheskoy Federativnoy Sovetskoy Respubliki utverzhdena V Vserossiyskim s'ezdom Sovetov 10 iiulia 1918 goda [Constitution (Fundamental Law) of the Russian Socialist Federative Soviet Republic Approved by the 5th All-Russian Congress of Soviets on July 10, 1918], In: SU RSFSR, 1918, No. 51, Art. 582.

32 See: Dekret Soveta Narodnykh Komissarov ob otkaze ot dogovorov pravitel'stva byv. Rossiyskoy Imperii s pravitel'stvami Germanskoy i Avstro-Vengerskoy imperiy, korolevstv Prussii i Bavarii, gertsogstv Gessena, Ol'denburga i Saksen-Meyningena i goroda Liubeka [Decree of the Council of People's Commissars on the Abolishment of the governmental treaties between the former Russian Empire and the governments of the German and Austro-Hungarian Empires, Kingdoms of Prussia and Bavaria, Grand Duchy of Hessen, Oldenburg and Saxe-Meiningen and the town of Lübeck] (1964). Art. 3, In: Dekrety Sovetskoy vlasti [Decrees of the Soviet Authorities]. Vol. III. July 11 - November 9, 1918. Moscow: Publishing House of Political Literature. P. 259. 
33 See: Dzidzoev, V.D., Levchenko, N.N. (2008). Separatizm, terrorizm i ekstremizm na Severnom Kavkaze: politico-pravovoy analiz [Separatism, Terrorism and Extremism in the Northern Caucasus: Political and Legal Analysis]. Vladikavkaz: Ir. P. 108.

34 See: Larin, A.G. (2003). Kitaytsy v Rossii vchera i segodnia [The Chinese in Russia Yesterday and Today]. Moscow: Muravey. P. 91.

35 See: Makarova, G.P. Op. cit. P. 37.

36 See: Dekrety Sovetskoy vlasti [Decrees of the Soviet Authorities]. Vol. I.P. 195-196.

37 See: Makarova, G.P. Op. cit. P. 37-38.

38 Dekrety Sovetskoy vlasti [Decrees of the Soviet Authorities]. Vol. I.P. 343.

39 Cit. ex: Chebotareva, V.G. (2003). Narkomnats RSFSR: Svet i teni natsional'noy politiki 1917-1924 gg. [Narkomnats of the RSFSR. Light and Shade of the Nationalities Policy of the Years 1917-1924]. Moscow: Social Academy of Sciences of the Russian Germans P. 324.

40 See: Bobrovnikov, V.O. (2001). Voenno-narodnoe upravlenie na Severnom Kavkaze (Dagestan): musul'manskaia periferiia v rossiyskom imperskom prostranstve, XIX-XX vv. [Military and Civilian Administration of the Northern Caucasus (Dagestan): Muslim Periphery of the Russian Imperial Space, 19-20th Centuries], In: Prostranstvo vlasti: istoricheskiy opyt Rossii i vyzovy sovremennosti [The Space of Power: Historical Experience of Russia and Contemporary Challenges]. Moscow. P. 378-388.

41 Mekulov, D.Kh. (1992). Natsional'no-gosudarstvennoe i sovetskoe stroitel'stvo v Adygee: nachal'nyy etap, tendentsii [National-Governmental and Soviet Building in Adygea: Initial Stage, Tendencies], In: Severnyy Kavkaz: natsional'nye otnosheniia (istoriografia, problemy) [Northern Caucasus: National Relations (Historiography, Problems)]. Edited by Bugay, M.F. Maykop. P. 68.

42 See: Zen'kovich, N. (2007). Geydar Aliev [Geydar Aliev]. Moscow: Iauza, Eksmo. P. 421.

43 DSV [Decrees of Soviet Authorities]. Vol. I.P. 185-186.

$44 \quad$ DSV [Decrees of Soviet Authorities]. Vol. I.P. 191.

45 See: Leybovich, O.L. (2017). Okhota na krasnogo direktora: monografiia [Hunting the Red Director: Monograph]. Perm: Titul Publishing House. P. 18.

46 See: Makarova, G.P. Op. cit. P. 32

47 The Narkomnats journal Zhizn' Natsional 'nostey (Life of Nationalities) stated, that often it was necessary 'just to search for certain persons standing on the Soviet platform to get them involved in the campaigns and propaganda of Soviet ideas among nationalities". Cit. ex: Makarova, G.P. Op. cit. P. 67.

48 Dekrety Sovetskoy vlasti [Decrees of the Soviet Authorities]. Vol. II. March 17 - July 10, 1918. Moscow: Publishing House of Political Literature, 1959. P. 450.

49 In July 1918, all parish and provincial councils of workers and peasants' deputies of the Northern Caucasus, Dagestan, Black Sea and Stavropol Provinces "in the presence of montane population" were suggested immediately to organize departments for the affairs of the montane population. In DSV [Decrees of Soviet Authorities], Vol. III. P. 116-117.

50 See: Chebotareva, V.G. P. 18-19.

51 See: Makarova, G.P. Op. cit. P. 32.

52 See: Volkhonskiy, M., Mukhanov, V. Op. cit. P. 102.

53 See: Ibid. P. 67.

54 See: Baku Commissars. Available at: http://ru.wikipedia.org

55 See: Volkhonskiy, M., Mukhanov, V.P. 92.

56 Cit. ex: Khalid, A. (2005). Turkestan v 1917-1922 godakh: bor'ba za vlast' na okraine Rossii [Turkestan in the Years 1917-1922: Fight for Power at the Edge of Russia], In: Tragediia velikoy derzhavy: natsional'nyy vopros i raspad Sovetskogo Soiuza [Superpower Tragedy: National Question and Collapse of the Soviet Union], Editor in Chief: Sevost'ianov, S.M. Moscow: Social-Political Thought Publishing House. P. 200.

57 See: Makarova, G.P.Op. cit. P. 71.

58 See: Morozova, I.Iu. (2005). Sotsial'nyy i natsional'nyy factory v obrazovanii Kirgizskoy SSR i Mongol'skoy Narodnoy Respubliki [Social and National Factors in the Establishment of the Kyrgyz Soviet Socialist Republic and the People's Republic of Mongolia], In: Tragediia velikoy derzhavy: natsional'nyy vopros i raspad Sovetskogo Soiuza [Superpower Tragedy: National Question and Collapse of the Soviet Union], Editor in Chief: Sevost'ianov, S.M., compiled by Iskhakov, R.M. Moscow: Social-Political Thought Publishing House. P. 245.

59 See: Ibid. P. 85-87.

60 See: Ibid. P. 90.

${ }_{61}$ DSV [Decrees of Soviet Authorities]. Vol. II. P. 435.

${ }^{62}$ DSV [Decrees of Soviet Authorities]. Vol. II. P. 436.

63 See: Makarova, G.P. Op. cit. P. 89.

64 See: Ibid. P. 87.

65 See: Ibid. P. 89-91.

66 See: Ibid. P. 89-90.

67 Narodnyy komissariat po delam natsional'nostey RSFSR [The People's Commissariat for Nationalities]. Available at: http://ru.wikipedia.org

68 Ibid. P. 176-177.

${ }_{69}$ Mineeva, E.K. (2006). Narkomnats RSFSR: tseli, zadachi, struktura [Narkomnats of the RSFSR: Objectives, Tasks, Structure], In: Vestnik Chuvashskogo universiteta [Chuvash University Newsletter], No. 7. P. 26.

70 See: Chebotareva, V.G. P. 29. 
See: Ibid. P. 37-41.

72 See: Makarova, G.P. Op. cit. P. 75.

See: Ibid. P. 80, 83.

74 See: Ibid. P. 77.

75 See: Ibid. P. 82.

76 See: Makarova, G.P.Op. cit. P. 25.

77 See: Ibid. P. 27.

78 See: Chebotareva, V.G.P. 269.

79 Cit. ex: Ibid. P. 270.

80 See: Ibid.

8126 iiulia. Predpisanie Sovetam Saratovskoy i Samarskoy guberniy ne dopuskat' samochinnykh deystviy po otnosheniiu k nemtsam-kolonistam [July 26. Instruction for the Councils of Saratov and Samara Provinces Not to Allow Unauthorized Actions Towards Colonist Germans], In: Dekrety Sovetskoy vlasti [Decrees of Soviet Authorities]. Vol. III. P. 100-101.

82 See: Makarova, G.P. Op. cit. P. 39.

83 See: Ibid. P. 40-41.

84 Ibid. Vol. 2. P. 361.

85 See: Istoriia otechestvennogo gosudarstva i prava. Chast' 2.: Uchebnik [History of Russian State and Law. Volume 2: Textbook], edited by Chistiakova, O.I. Edition 3, updated and revised. Moscow: Yurist Publishing House, 2004. P. 61-62.

86 Stalin, J.V. Vol. 4. P. 87-89.

87 Ibid. P. 73.

88 See: Chebotareva, V.G. Op. cit. P. 7.

89 Cit. ex: Chebotareva, V.G. P. 84-85.

$90 \quad$ Cit. ex: Ibid. P. 86.

91 Stalin, J.V.Vol. 4. P. 88.

92 See: Chebotareva, V.G. Op. cit. P. 91.

93 See: Ibid. P. 92.

94 Cit. ex: Ibid. P. 94.

95 See: Makarova, G.P. Op. cit. P. 49.

96 See: Ibid. P. 60.

97 See: Dubinskiy-Mukhadze, I.M. (1978). In Narimanov [Narimanov]. Moscow: Molodaia Gvardiia. P. 158.

98 See: Kozlov, V.I. (1977). Izmeneniia v rasselenii i urbanizatsiia narodov SSSR kak usloviia i factory etnicheskikh protsessov [Changes in the Settlement and Urbanization of the USSR Nations as Conditions and Factors for Ethnic Processes], In: Sovremennye etnicheskie protsessy v SSSR [Contemporary Ethnic Processes of the USSR], Edition 2. Moscow: Nauka Publishing House. P. 151.

99 See: Kordonskiy, S. (2010). Rossiia. Pomestnaia federatsiia [Russia. The Manorial Federation]. Moscow: Evropa Publishing House. P. 20.

100 Lenin, V.I. (1973). Kriticheskie zametki po natsional'nomy voprosu [Critical Remarks on the National Question], In: Lenin, V.I. PSS [Complete Works]. Vol. 24. Moscow: Publishing House of Political Literature. P. 149.

101 See: Administrativno-territorial'noe ustroystvo Rossii. Istoriia i sovremennost' [Administrative and Territorial Structure of Russia. History and Contemporariness]. Moscow: OLMA-PRESS, 2003. P. 218.

102 See: Ibid. P. 208.

103 See: Guibernau, M. (1999). Nations without States: Political Communities in a Global Age. Malden, MA, USA: Blackwell publishers Inc. P. 52-53.

104 Lenin, V.I.PSR [Complete Works]. Vol. 24. P. 133.

105 Ibid. P. 139.

106 Ibid. P. 142.

107 Seе: Такер У. Op. cit. Р. 149.

108 Stalin, J.V.Vol. 4. P. 165.

109 See: Rossiyskaia gosudarstvennost'v terminakh: IX-nachalo XX v. Slovar' [Russian State in Terms: the $9^{\text {th }}-$ Early $20^{\text {th }}$ Centuries. Dictionary]. Moscow: Kraft + Publishing House, 2001. P. 188.

110 Cit. ex: Nam, I.V. Kul'turno-natsional'naia avtonomiia v Rossii: opyt Dal'nevostochnoy respubliki (1921-1922) [CulturalNational Autonomy in Russia: The Far East Republic Experience], In: Tragediia velikoy derzhavy: natsional'nyy vopros $i$ raspad Sovetskogo Soiuza [Superpower Tragedy: National Question and Collapse of the Soviet Union]. P. 181-182.

11125 iiulia. Postanovlenie o bor'be s antisemitizmom i evreyskimi pogromami [Decree Regarding the Fight against Antisemitism and Jewish Pogroms] (1964). In: Dekrety Sovetskoy vlasti [Decrees of the Soviet Authorities]. Volume III. July 11 - November 9, 1918. Moscow: Political Literature Publishing House. P. 93-94.

112 DSV [Decrees of the Soviet Authorities]. Volume III. P. 291-292.

113 Lenin, V.I.PSR [Complete Works]. Vol. 44. P. 174.

114 See: Makarova, G.P.Op. cit. P. 98-99.

115 See: Chebotareva, V.G. Op. cit. P. 330-331.

116 See: Makarova, G.P.Op. cit. P. 146.

117 See: Selishchev, A.M. (2010). Iazyk revoliutsionnoy epokhi. Iz nabliudeniy nad russkim iazykom (1917-1926) [The Language of the Revolutionary Epoch. Observations over Russian Language (1917-1926)]. Third edition. Moscow: LIBROKOM Book House. P. 218.

118 See: Ibid. P. 219-224. 


\section{References}

Administrativno-territorial'noe ustroystvo Rossii. Istoriia i sovremennost' [Administrative and Territorial Structure of Russia. History and Contemporariness] (2003). Moscow: OLMA-PRESS.

Berne, E. (2008). Lider i gruppa. O strukture i dinamike organizatsiy i grupp [Lider and Group. Structure and Dynamics of Organizations and Groups]. In Eric Berne [translated from English by A. Gruzberg]. Moscow: Eksmo.

Bobrovnikov, V.O. (2001). Voenno-narodnoe upravlenie na Severnom Kavkaze (Dagestan): musul'manskaia periferiia v rossiyskom imperskom prostranstve, XIX-XX vv. [Military and Civilian Administration of the Northern Caucasus (Dagestan): Muslim Periphery of the Russian Imperial Space, 19-20 ${ }^{\text {th }}$ Centuries], In: Prostranstvo vlasti: istoricheskiy opyt Rossii i vyzovy sovremennosti [The Space of Power: Historical Experience of Russia and Contemporary Challenges]. Moscow. P. 372-390.

Carr, E. (1990) Istoriia Sovetskoy Rossii. Kn. 1: Tom 1 i 2. Bol'shevistskaia revoliutsiia. 1917-1923 [A History of Soviet Russia. Book 1: Volumes 1 and 2. Bolshevik Revolution. 1917-1923]. Translated from English/Introduction by Nenarokov A.P. Moscow: Progress.

Chebotareva, V.G. (2003). Narkomnats RSFSR: Svet i teni natsional'noy politiki 1917-1924 gg. [Narkomnats of the RSFSR. Light and Shade of the Nationalities Policy of the Years 1917-1924]. Moscow: Social Academy of Sciences of the Russian Germans.

Dekrety Sovetskoy vlasti. Tom I. 25 oktiabria 1917 g. - 16 marta 1918 g. [Decrees of Soviet Authorities. Volume I. October 25, 1917 - March 16, 1918$]$ (1957). Moscow: Political Literature Publishing House.

Dekrety Sovetskoy vlasti. Tom II. 17 marta - 10 iiulia 1917 g. [Decrees of Soviet Authorities. Volume II. March 17 - July 10, 1917] (1959). Moscow: Political Literature Publishing House.

Dekrety Sovetskoy vlasti. Tom III. 11 iiulia - 9 noiabria 1918 g. [Decrees of Soviet Authorities. Volume III. July 11 - November 9, 1918] (1964). Moscow: Political Literature Publishing House.

Dzidzoev, V.D., Levchenko, N.N. (2008). Separatizm, terrorizm i ekstremizm na Severnom Kavkaze: politico-pravovoy analiz [Separatism, Terrorism and Extremism in the Northern Caucasus: Political and Legal Analysis]. Vladikavkaz: Ir.

Dubinskiy-Mukhadze, I.M. (1978). Narimanov [Narimanov]. Moscow: Molodaia Gvardiia.

Guibernau, M. (1999). Nations without States: Political Communities in a Global Age. Malden, MA, USA: Blackwell publishers Inc.

Iakunin, V.I., Bagdasarian, V.E., Sulakshin, S.S. (2009). Novye tekhnologii bor'by s rossiyskoy gosudarstvennost'iu [New Technologies of Fight Against the Russian State]. Moscow: Nauchnyy Ekspert.

Istoriia otechestvennogo gosudarstva i prava. Chast' 2.: Uchebnik [History of Russian State and Law. Volume 2: Textbook], edited by Chistiakova, O.I.Edition 3, updated and revised. Moscow: Yurist Publishing House, 2004.

Khalid, A. (2005). Turkestan v 1917-1922 godakh: bor'ba za vlast' na okraine Rossii [Turkestan in the Years 1917-1922: Fight for Power at the Edge of Russia], In: Tragediia velikoy derzhavy: natsional'nyy vopros i raspad Sovetskogo Soiuza [Superpower Tragedy: National Question and Collapse of the Soviet Union], Editor in Chief: Sevost'ianov, S.M., compiled by Iskhakov, R.M.Moscow: Social-Political Thought Publishing House. 
Kozlov, V.I. (1977). Izmeneniia v rasselenii i urbanizatsiia narodov SSSR kak usloviia i factory etnicheskikh protsessov [Changes in the Settlement and Urbanization of the USSR Nations as Conditions and Factors for Ethnic Processes], In: Sovremennye etnicheskie protsessy v SSSR [Contemporary Ethnic Processes of the USSR], Edition 2. Moscow: Nauka Publishing House.

Konstitutsiia (Osnovnoy zakon) Rossiyskoy Sotsialisticheskoy Federativnoy Sovetskoy Respubliki utverzhdena V Vserossiyskim s'ezdom Sovetov 10 iiulia 1918 goda [Constitution (Fundamental Law) of the Russian Socialist Federative Soviet Republic Approved by the $5^{\text {th }}$ All-Russian Congress of Soviets on July 10, 1918], In: SU RSFSR, 1918, No. 51, Art. 582.

Kordonskiy, S. (2010). Rossiia. Pomestnaia federatsiia [Russia. The Manorial Federation]. Moscow: Evropa Publishing House.

Krasnov, P.N. (2003). Na vnutrennem fronte; V donskoy stanitse pri bol'shevikakh; Vsevelikoe Voysko Donskoe [At the Domestic Frontline. In a Don Stanitsa in the Time of Bolsheviks; The All Great Don Host]. Moscow: Ayris Press. P. 263.

Kunitsyn, I.G. (1989). Samoopredelenie natsiy - istoriia voprosa i sovremennost' [SelfDetermination of Nations: History and Contemporariness], In: Voprosy filosofii [Philosophy Questions]. No. 5. P. 85.

Larin, A.G. (2003) Kitaytsy v Rossii vchera i segodnia [The Chinese in Russia Yesterday and Today]. Moscow: Muravey.

Leybovich, O.L. (2017). Okhota na krasnogo direktora: monografia [Hunting the Red Director: Monograph]. Perm: Titul Publishing House.

Lenin, V.I. (1973). Kriticheskie zametki po natsional'nomy voprosu [Critical Remarks on the National Question], In: Lenin, V.I.PSS [Complete Works]. Vol. 24. Moscow: Publishing House of Political Literature. P. 113-150.

Lenin, V.I. (1967). Natsional'nyy vopros v nashey programme [The National Question in Our Programme], In: Lenin, V.I. PSS [Complete Works]. $5^{\text {th }}$ edition. Vol. 7. Moscow: Publishing House of Political Literature. P. 233-242.

Lenin, V.I. (1967). Proekt rezoliutsii o meste Bunda v RSDRP [Draft Resolution on the Place of the Bund in the Party], In: Lenin, V.I.PSS [Complete Works]. $5^{\text {th }}$ edition. Vol. 7. Moscow: Publishing House of Political Literature. P. 245.

Lenin, V.I. (1969). Sotsialisticheskaia rezoliutsiia i parvo natsiy na samoopredelenie [Socialist Revolution and the Right of Nations to Self- Determination], In: Lenin, V.I. PSS [Complete Works]. $5^{\text {th }}$ edition. Vol. 27. Moscow: Publishing House of Political Literature. P. 252-266.

Makarova, G.P. (1987). Narodnyy komissariat po delam natsional'nostey RSFSR. 1917-1923 gg. Istoricheskiy ocherk [People's Commissariat for Nationalities in the RSFSR. Years 1917-1923. Historical Essay]. Moscow: Nauka.

Machiavelli, N. (1990). Gosudar' [Prince]. Moscow: Planeta.

Mekulov, D.Kh. (1992). Natsional'no-gosudarstvennoe i sovetskoe stroitel'stvo v Adygee: nachal'nyy etap, tendentsii [National-Governmental and Soviet Building in Adygea: Initial Stage, Tendencies], In: Severnyy Kavkaz: natsional'nye otnosheniia (istoriografia, problemy) [Northern Caucasus: National Relations (Historiography, Problems)] / Edited by Bugay, M.F. Maykop.

Mineeva, E.K. (2006). Narkomnats RSFSR: tseli, zadachi, struktura [Narkomnats of the RSFSR: Objectives, Tasks, Structure], In: Vestnik Chuvashskogo universiteta [Chuvash University Newsletter], No. 7. 
Morozova, I.Iu. (2005). Sotsial'nyy i natsional'nyy factory v obrazovanii Kirgizskoy SSR i Mongol'skoy Narodnoy Respubliki [Social and National Factors in the Establishment of the Kyrgyz Soviet Socialist Republic and the People's Republic of Mongolia], In: Tragediia velikoy derzhavy: natsional'nyy vopros i raspad Sovetskogo Soiuza [Superpower Tragedy: National Question and Collapse of the Soviet Union], Editor in Chief: Sevost'ianov, S.M., compiled by Iskhakov, R.M. Moscow: Social-Political Thought Publishing House.

Nam, I.V.Kul'turno-natsional'naia avtonomiia v Rossii: opyt Dal'nevostochnoy respubliki (19211922) [Cultural-National Autonomy in Russia: The Far East Republic Experience], In: Tragediia velikoy derzhavy: natsional'nyy vopros i raspad Sovetskogo Soiuza [Superpower Tragedy: National Question and Collapse of the Soviet Union]. P. 181-182.

O natsional'noy politike partii v sovremennykh usloviiakh. Doklad General'nogo sekretaria TSK KPSS M.S. Gorbacheva. 19 Sentiabria 1989 g. Materialy Plenuma Tsentral'nogo Komiteta KPSS, 1920 sentiabria 1989 g. [On the Nationalities' Policy of the Party in the Modern Conditions. The Speech of the General Secretary of the Central Committee of the Communist Party of the USSR Gorbachev, M.S. September 19, 1989. Proceedings of the Plenum of the Central Committee of the Communist Party of the Soviet Union, September 19-20, 1989] (1989). Moscow: Politizdat.

Omel'chenko, N.A. (2008). Istoriia gosudarstvennogo upravleniia v Rossii [History of State Administration in Russia]. Moscow: Prospect.

Rossiyskaia gosudarstvennost'v terminakh: IX-nachalo XX v. Slovar' [Russian State in Terms: the $9^{\text {th }}$ - Early $20^{\text {th }}$ Centuries. Dictionary] (2001). Moscow: Kraft + Publishing House.

Selishchev, A.M. (2010). Iazyk revoliutsionnoy epokhi. Iz nabliudeniy nad russkim iazykom (19171926) [The Language of the Revolutionary Epoch. Observations over Russian Language (1917-1926)]. Third edition. Moscow: LIBROKOM Book House.

Speech of Khrushchev at the $20^{\text {th }}$ Congress of the Party. Available at: http://www.coldwar.ru/ hrushev/cult_of_personality.php

Stalin, J.V. (1946). VII (aprel'skaia) konferentsiia RSDRP (b). Zakliuchitel'noe slovo po natsional'nomu voprosu. 29 aprelia [ $7^{\text {th }}$ (April) Conference of Russian Socialist Democrat Labour Party of the Bolsheviks. Final Word on the National Question. April, 29], In: Stalin, J.V. Sochineniia [Works]. Vol. 3. Moscow: OGIZ.P. 55-57.

Stalin, J.V. (1946). Marksizm i natsional'nyy vopros [Marxism and the National Question], In: Stalin, J.V.Sochineniia [Works]. Vol. 2. Moscow: OGIZ. P. 290-367.

Stalin, J.V. (1947). Politika pravitel'stva po natsional'nomu voprosu [Policy of the Soviet Government on the Nationa Question in Russia], In: Stalin, J.V. Sochineniia [Works]. Vol. 4. Moscow: OGIZ.P. 225-229.

Stalin, J.V. (1946). Protiv federalizma [Against Federalism], In: Stalin, J.V. Sochineniia [Works]. Vol. 3. Moscow: OGIZ.P. 23-31.

Stalin, J.V. (1947). XII s'ezd RKP (b). Doklad o natsional'nykh momentakh v partiynom i gosudarstvennom stroitel'stve $\left[12^{\text {th }}\right.$ Congress of RCP (b). Speech on the National Moments in the Party and State Building], In: Stalin, J.V. Sochineniia [Works]. Vol. 5. Moscow: OGIZ. P. 236-263.

Tucker, R. (1991). Stalin. Put' k vlasti 1879-1929. Istoriia i lichnost' [Stalin as Revolutionary. 1879-1929. History and Personality]. Translated from English, edited and afterword by Lel'chuk, B.S. Moscow: Progress. 
Tishkov, V.A. (2005). Etnologiia i politika [Ethnology and Politics]. Moscow: Nauka.

Volkhonskiy, M., Mukhanov, V. (2007). Po sledam Azerbaydzhanskoy demokraticheskoy respubliki [Following Azerbaijan Democratic Republic], Moscow: Europe Publishing House.

Zen'kovich, N. (2007). Geydar Aliev [Geydar Aliev]. Moscow: Iauza, Eksmo.

\title{
Национальная политика первого года \\ Советской власти
}

\author{
С.А. Подъяпольский \\ Юридическое агентство «Антикризисный иентр» \\ Россия, 660075, Красноярск, ул. Маерчака, 8/9
}

\begin{abstract}
На основе анализа первоисточников автор представляет «ленинскую национальную политику» не как начетническое развертывание умозрительно выведенной доктрины, а как гибкий набор политических тактик, соответствовавших актуальной общественно-политической ситуации, задаче удержания власти и общим политико-экономическим задачам Советского правительства. В числе тактических приемов, использовавшихся в этот период большевиками, автор рассматривает декларации, обещуания, подарки, тактические компромиссы, терпимость в обмен на политическую лояльность, использование попутчиков, формирование национальных воинских подразделений, создание центральных и местных органов управления этносоциальными прочессами, агитацию и пропаганду, создание национально-территориальных автономий и борьбу за контроль над образовательными учреждениями.
\end{abstract}

Ключевые слова: большевики, Наркомнац, национальное строительство, пропаганда, советская национальная политика.

Научная специиальность: 24.00 .00 - культурология. 